УДК: $7.032(38)$

ББК: $63.48,85.103(0) 32,85.113(0) 32$

DOI: $10.18688 / \mathrm{aa} 2111-01-15$

E. Korka, M. Lefantzis, A. Corso

\title{
New Finds Regarding the Architecture and Sculptures of Ancient Tenea
}

Excavations in 2019 and 2020 in ancient Tenea, Corinthia, revealed a main part of the city's central web with public buildings totaling approximately 1.100 square meters. In particular, part of a public bath complex of Roman times was excavated, as well as part of an area of the Archaic times of religious significance (Fig. 1). These remains were found to the west and in a short distance from the residential buildings excavated in 2018 and provide important information about the central public spaces of the ancient city.

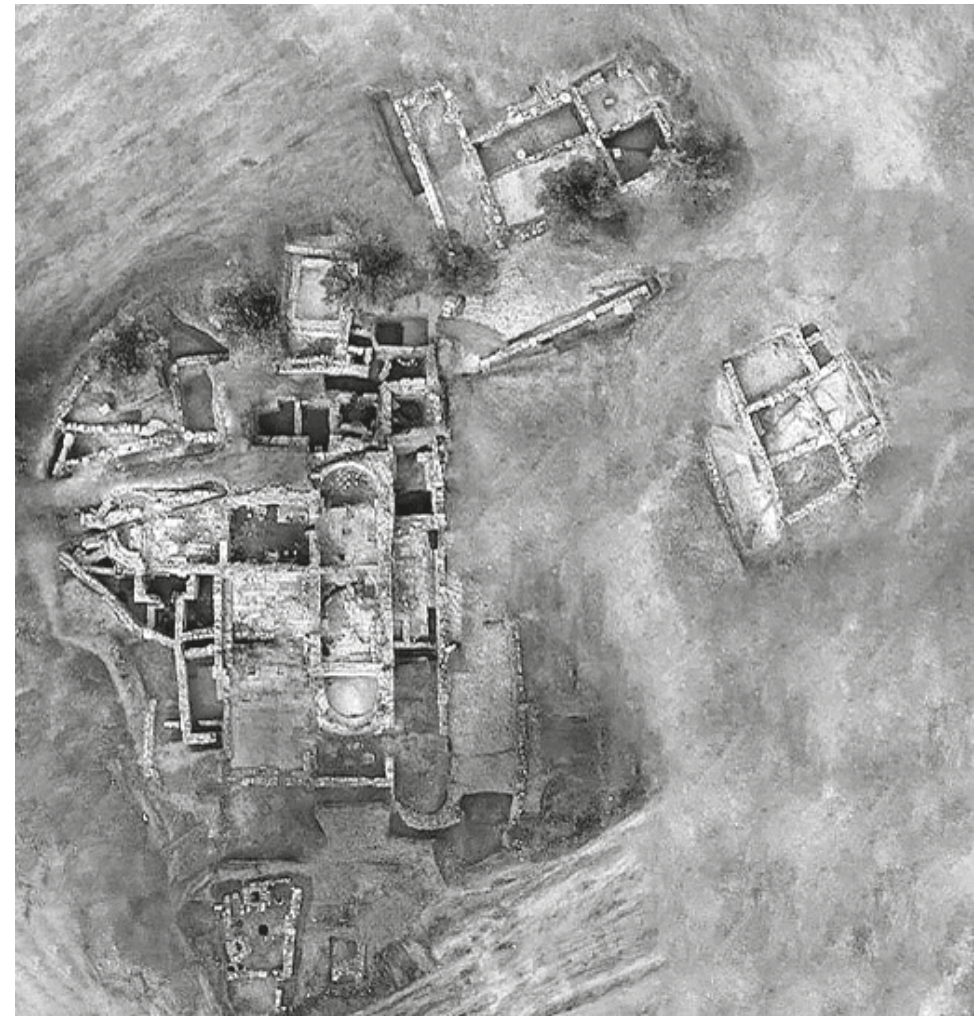

Fig. 1. The Roman Bath Complex of Ancient Tenea.Courtesy of Dr. Eleni Korka 
The baths are N / S oriented and date to the imperial times. In the northern part of the excavated area, three chambers with an E / W axis were identified, which communicate with each other through door openings and are identified as heated rooms (two caldaria and one sudatorium) [19, pp. 159-160]. In all of them, the beneath the floor heating system with circular and square heating pillars (suspensurae) [20, p. 266] is preserved. Three praefurnia were constructed, one for each room, while ventilation pipes (tubuli) [30, p. 363] were used to release the hot air. However, the praefurnium of the eastern room was found sealed, indicating that it was probably in use only in the first phase of the use of the baths. Finally, the western room ends in a buttressed apse [7, p.292], while the eastern room ends in an inscribed apse, both of which inside had a cistern of water (alveus) [19, pp. 154-158]. Both rooms were luxuriously decorated as one can argue from the marble inlays and fragments of red painted mortar.

Four chambers were identified in the south excavated section of the complex. One of them (62 sq.m), the "apodyterium" [30, p. 34], carries built-in benches all around its walls. A colonnade runs through this room, with an E / W direction. On its floor a fallen Ionic capital and a column were found. This room communicates to the east with a rectangular room with remains of a bathtub, which in turn connects to the north with the caldarium and to the south with a swimming pool [19, pp.154-158]. South of the pool, one more room was located, where remains of bathtubs and footbaths were found.

To the east, a third room was revealed, with residues of a third apse. Inside this area a destruction layer was found, with a fallen Doric capital and a column drum. The room includes extensive clay flooring preserved in extremely good condition, a bathtub and a lead duct, on the surface of which probably the name of the manufacturer was inscribed [26, p. 141].

Finally, in the SW part of the baths, a room was detected, where a drainage pipe facilitating other chambers, used to end up [18, pp.50-51]. In this area, deposits of utilitarian pottery of the Hellenistic and Roman times, a clay figurine head, several fragments of elaborate glass perfume pots, as well as fragments of glass strips placed on mortar were found. In general, elaborate facilities connected with water supply were located both to the southwest and to the north of the building. More specifically, a cistern of water, coated with mortar [20, pp. 263-264] was found to the north of the complex.

At the same time, auxiliary spaces, one of which was probably associated with the storage of wood for the praefurnium were located next to the cistern [21, p.56]. Worth mentioning as main features of these rooms are the architectural members of previous periods, found in second use (spolia), as parts of the walls. Members such as triglyphs, architraves, cornices, and column drums indicate the existence of large Archaic public buildings in the vicinity of the bath complex.

To the north, in direct contact with the baths and at a greater depth, Archaic period installations, including a hexagonal well, were identified within a space defined by walls arranged in a " $\Pi$ " shape. Inside this area, in an Archaic pottery layer, a section of a thigh from a statue made of exquisite Parian marble, as well as other parts of sculptures were found. Immediately east of the well, an underground archaic deposit storeroom was excavated. The finds mostly constitute of miniature vases, (Fig. 2, 4, 5), figurines (Fig. 3) and metal objects. More specifically, the absence of human skeletal remains on the one side and the existence of miniature vases in the deposit on the other, like the kalathiskos and the phiale, indicate that the deposit was part of a vo- 


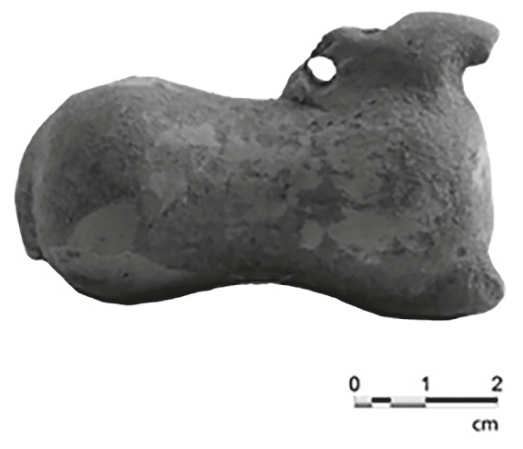

Fig. 2. Hare Shaped Aryballos.Courtesy of Dr. Eleni Korka

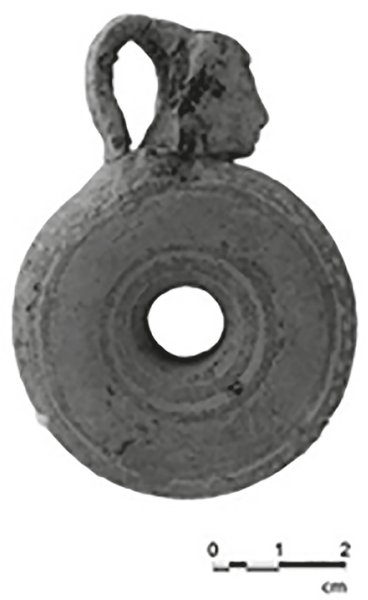

Fig. 4. Ring Aryballos. Courtesy of Dr. Eleni Korka
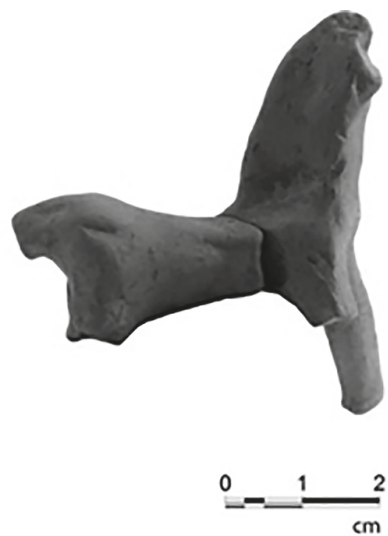

Fig. 3. Clay Horse Figurine. Courtesy of Dr. Eleni Korka

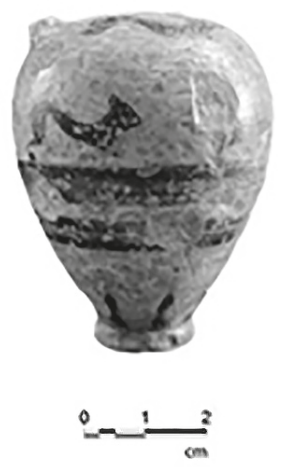

Fig. 5. Pointed Aryballos. Courtesy of Dr. Eleni Korka

tive context [23, pp.281-338]. Other findings that characterize the votive use of the deposit are a red-colored "astragalos", two iron miniature offering tables, a bronze pin and a bronze ring.

From the inside of the well, which was explored at a depth of $15 \mathrm{~m}$, a large amount of architectural members of the Archaic, Classical and Hellenistic periods, a decorated tile, "simae", a marble statuette base, on which a dog and legs of a male figure were preserved, possibly of Meleager, a statue of a naked female, most probably Aphrodite, 60 amphorae and oinochoai, pottery from Archaic to Late Roman times, coins of Roman and Late Roman times, and a spear head from an iron spear were found. The above-mentioned remains lead to the assumption that there must have been a place of worship, which probably was part of a larger public archaic religious complex extending to areas not yet explored. 
In general, the bath complex seems to have been originally constructed in the $2^{\text {nd }}$ century A. D., with several interventions and reconstructions happening in the following centuries, until the late Roman times.

Most extraordinary is the discovery of two inscriptions found built inside the walls of the bath complex. More specifically, the first was part of a public inscription of the $5^{\text {th }}$ century B.C. with a

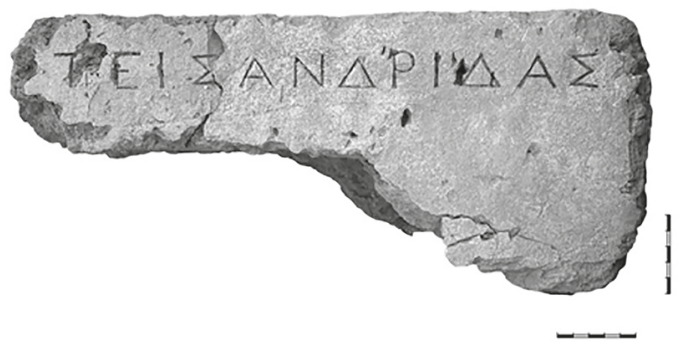

Fig. 6. Stone pedestal of a statue and dates to the $4^{\text {th }}$ century B.C. Courtesy of Dr. Eleni Korka red painted corniche at the top of both sides. Next to the inscription, a silver obol from Argos, from the $5^{\text {th }}$ century B.C. was located. The second inscription was located on a stone pedestal of a statue. It dates to the $4^{\text {th }}$ century B. C. and bears the name TEI $\Sigma A N \Delta \mathrm{PI} \Delta \mathrm{A} \Sigma$ (Teisandridas) (Fig. 6).

In the eastern part of the area, extensive and strong building facilities of 282 square meters were discovered on a north-south axis, which are identified as areas of commercial activity. These areas are connected to the bath complex via a cobbled road. Artifacts connected to the commercial activity that took place in this area were found, such as a bronze balance with an inscription, millstones, glass and ceramic vases, a bronze miniature spoon, jewelry, objects of iron such as hairpins, brooches, blades, nails, etc. Moreover, an iron spearhead, a stone inscription in second use, a clay inscription and over 300 coins were also revealed. Among the latter, four numismatic hoards, from which one of seventy-two bronze coins of the $5^{\text {th }}$ century A.D. and one of twenty-nine solidi and a semissis (half solidus), of emperors Marcian, Justin I and Justinian (period of issue from 450 to $565 \mathrm{AD}$ ), as well as a gold ring were discovered [14] (Fig. 7). In the area between the bath complex and the commercial facilities, walls were revealed, which seem to surround a new space, which will be systematically explored in the following period. Finally, south of the baths an artisan workshop of 47 square meters was located, related to the procession of iron.

In conclusion, the excavated area in 2019 and 2020 so far proves the diachronic continuity of the city center from the $6^{\text {th }}$ century B. C. till the $6^{\text {th }}$ century $\mathrm{AD}$, bringing to light elements of the history of the city: not only luxurious buildings of the city civic center were revealed, but also historical events, such as natural disasters and barbaric raids, can be argued from the architectural remains and the various finds. Above all, what is truly remarkable is the abundance of important architectural members from public archaic buildings, which were incorporated in the masonry of Roman buildings.

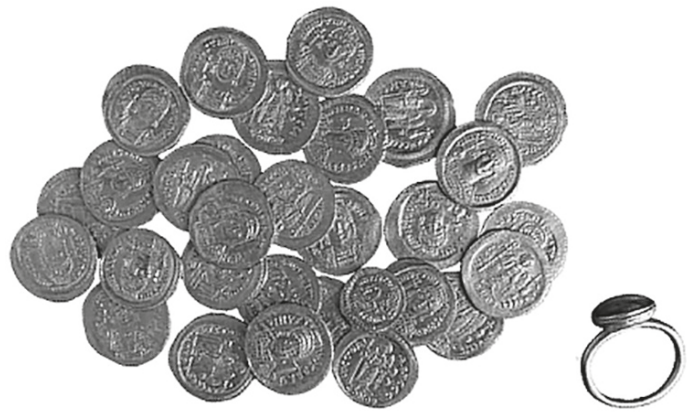

Fig. 7. Byzantine gold hoard from Tenea $5^{\text {th }}-6^{\text {th }}$ century A. D. and a golden ring. Courtesy of Dr. Eleni Korka 


\section{Sculptures of ancient Tenea}

A marble left thigh of a statue of a male subject has been found in September 2019 near the baths of Tenea (Fig. 8, 1). It was associated with archaic pottery. The marble of this fragment looks Parian and its polishing is typical of the early $5^{\text {th }}$ century BC. Its quality is outstanding. The thigh is well worked in front and on both sides: this fact implies that the statue was characterized either by open legs or by one leg more advanced than the other. The thigh looks similar to the corresponding parts of the examples of the Omphalos type of Apollo [22, pp.55-84]. Perhaps this statue from Tenea represented Apollo and may be linked to the cult of Apollo Teneatis, which is known from Strabo 8. 380. The original surface of the thigh, when preserved, is fresh and not weathered, thus this statue, which was around 1,6 -1.65 m high, once stood inside a building.
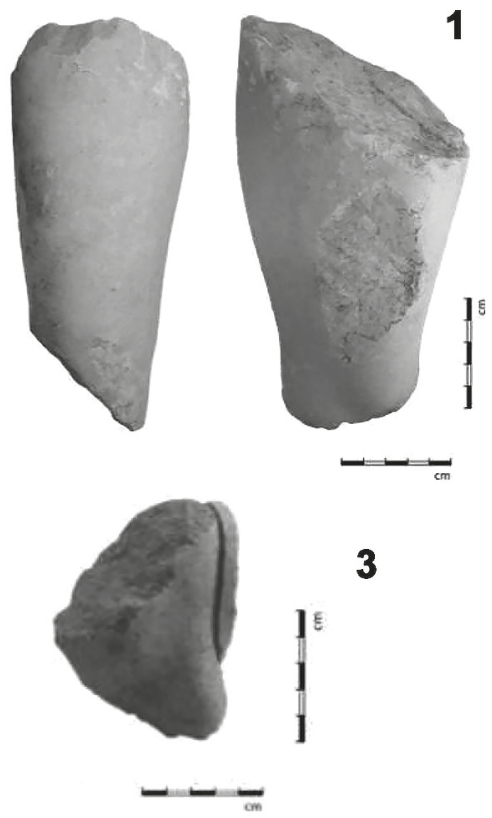

5
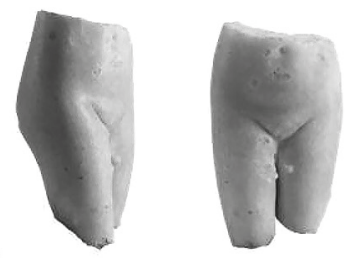

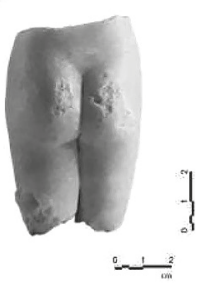

2
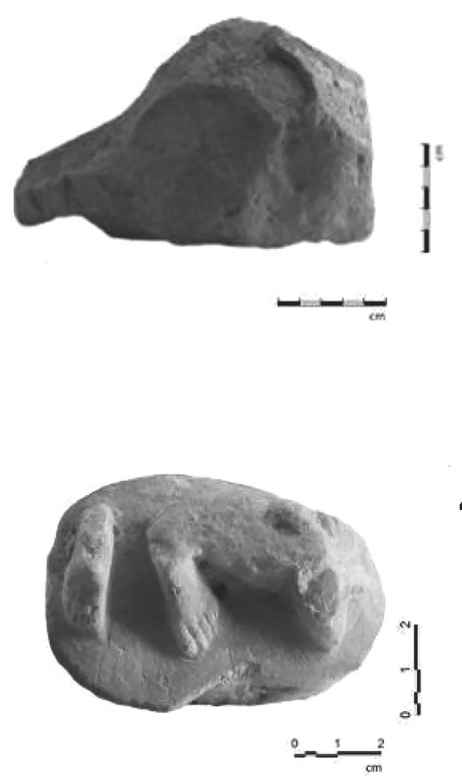

4

6
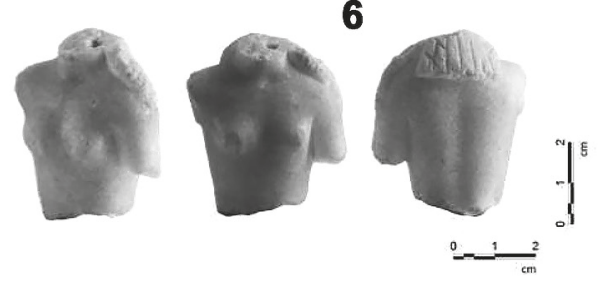

Fig. 8. Fragments of sculptures from the excavation of Tenea, Chiliomodi, antiquities storeroom. Courtesy of Dr. Eleni Korka 
A limestone fragment probably represents a damaged tree trunk above the base; the trunk has an oblique inclination: the same diagonal configuration characterizes also the tree trunk at the left side of the sculptural type of the Protesilaos [11, pp.207-233]. The display of an image of this Greek warrior killed by Trojans at Tenea would suggest that the inhabitants of this town, who regarded themselves Trojan, as we know from Pausanias 2. 5. 4, would feel proud of their prevalence upon this Greek hero. The dating of this sculpture may be middle Hellenistic because a later sculpture would be a marble one and an earlier statue would not imitate so closely an opus nobile.

A limestone triangular fragment might have been perhaps in the viewer's left corner of a pediment's tympanum (Fig. 8,2). The rugged external surface may be meant to represent a rocky hill or mountain as in the slabs of the Mantinean Muses [15, pp. 83-89]. The dating and craftsmanship of this piece appear the same of the above considered tree trunk.

Other four sculptures, some from the excavation and some found out of contexts, were parts of marble statuettes. Certain of these are of the type which is known from many examples especially on Delos [9, pp. 177-184] and in the agora of Athens [27, pp. 267-342] and date to the late $2^{\text {nd }}$ century BC or in the early $1^{\text {st }}$ century BC. Their main feature is the following: these small sculptures are not fully polished but the natural brilliance of marble surfaces is preserved in some parts.

A fragment preserves a female right shoulder crossed by a strap which probably implies the original presence of a quiver in the back of the statuette (Fig. 8, 3): the right arm was brought up, thus probably in order to take an arrow from the quiver. Probably the sitter was Artemis: the goddess was represented according to the Dresden or Versailles or Malta types of this goddess, which are characterized by the above outlined action made with the right arm of the goddess [4, pp. 121-123]. Another possibility is that it represents the fragment of a reduced copy of the Sciarra or Sosikles types of Amazon [1]. An alternative interpretation is that the fragment preserves a foot standing on a ground.

The lower fragment of one of these statuettes is preserved (Fig. 8, 4): it bears the base elliptical and irregular - and supports on the viewer's left the feet of a man and, at the right, a dog, which lies on the ground with two legs brought forward. An example from Corinth whose base is nearly identical to our base $[10,55$, no. 71$]$ probably should be attributed to the same workshop. The feet of the male sitter bear the same positions of the feet of the Vatican type of Meleager, which usually is attributed to Skopas [17, pp. 157-166], while the position of the upper part of the dog imitates the similar features of the Munich type dog [28, p. 183]. Thus, the representation of Meleager with his dog is likely in this case.

Another marble statuette is female and survives in the lower part of the belly, the bottom, the pubes, and the thighs (Fig. 8,5). This section makes it clear that the statuette was once a copy of the Cnidian Aphrodite, which was similar to the many late Hellenistic marble statuettes of the goddess in this style which have been found everywhere in the Aegean world [5, pp. 72-81].

Finally, a headless marble female torso of a statuette has also been found (Fig. 8, 6). The upper parts of the arms survive: the left arm was lowered, while the right arm was uplifted. Thus, the statuette was a miniature copy of the cult statue of Aphrodite made by Hermogenes of Cythera for the temple of Aphrodite in the Agora of Corinth. This goddess had her left arm 


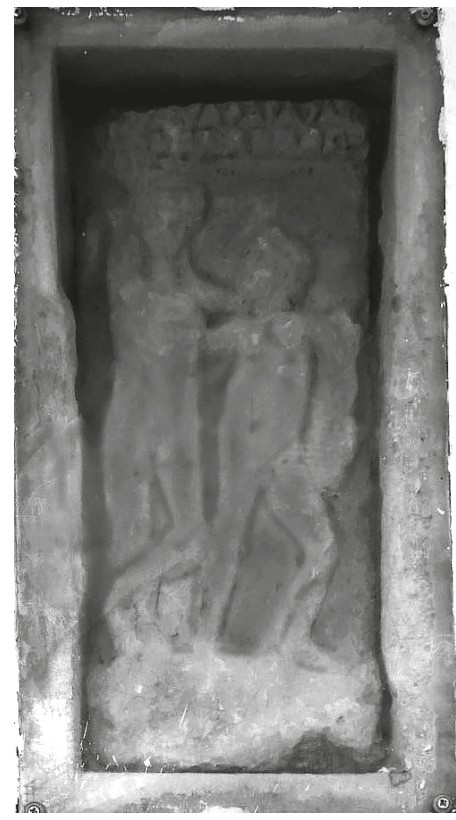

Fig. 9. Relief walled in the cathedral of Chiliomodi. Courtesy of Dr. Eleni Korka lowered in order to hold the case for a mirror, while her right arm was uplifted to wreath herself [6, pp. 80-89]. The configuration of this Corithian statue is known thanks to coin types struck under Julia Domna and Caracalla [6, figs. 3 and 4], to the marble statuette at Corinth, Museum, no. 1181 [6, fig. 5], as well as to a statuette of Corinthian production from Thera at Berlin, Altes Museum, Antikensammlung, no. 7101 [6, fig. 6].

These statuettes reveal the reception of copies of renowned masterpieces by important masters in middle to late Hellenistic Tenea.

Finally, a stone relief is walled in the walls of the main church of Chiliomodi, a modern village inside the territory of ancient Tenea (Fig. 9). The panel represents a young, naked Dionysus held by a Satyr. The god appears beard-less, his right arm is brought to the top of his head, a gesture which usually is meant to suggest a resting attitude. His crossed legs express an unstable stance. His left arm rests on the shoulder of a Satyr. The Satyr bears deep pathetic eyes, is bearded, his right arm is brought to the back of the god, his left arm is lowered and brought to his left leg, his legs are wide apart. This type of symplegma is very well known by many examples from any part of the Hellenistic world and which cover a chronological span from the late $4^{\text {th }}$ century BC until the $4^{\text {th }}$ century AD $[24$, pls. $8-15 ; 22$; 24-25; 28-29; 34-39; 41-43; 54-59; 61-82]. A Dionysos from Argos (Archaeological Museum $[25$, p. 40 , no. G 5, pl. 13]) is also naked, with his right arm brought on top of his head and with his legs crossed; and it is dated the late $2^{\text {nd }}$ century AD. Probably the same date should be given also to the relief from Tenea, which for this reason may be attributed to an Argive workshop.

This example reveals the reception in middle imperial Tenea of a visual culture based on schemata nobilia.

\section{About Hermes}

The relief block (with general dimensions $0,9 \times 0,5 \times 0,25 \mathrm{~m}$ ) which represents Hermes, is made by a local marble and its elaboration is made with tooth and point chisel (Fig. 10). The partial use of a tongue chisel, indicates the Roman dating of its construction. A three-side meander band defines the frame for the Hermes portrait.

At the right side of the marble block, a rectangular pilaster is incorporated to the relief. The non-fluted part of this pilaster reaches the height of $0,6 \mathrm{~m}$. This geometrical datum informs us of the exact eye level of the people passing in front of the monument, in which the relief belonged initially (Fig. 11). As we can see at the section of the block, on the sides, there is a rectangular shaped thrust joint, negative on the left side and positive on the right side. The side faces of this relief had identical thrust joins, dimensions, and architectural characteristics (meander band and incorporated pilaster) in order to create an entire structural zone, an ensemble. The 


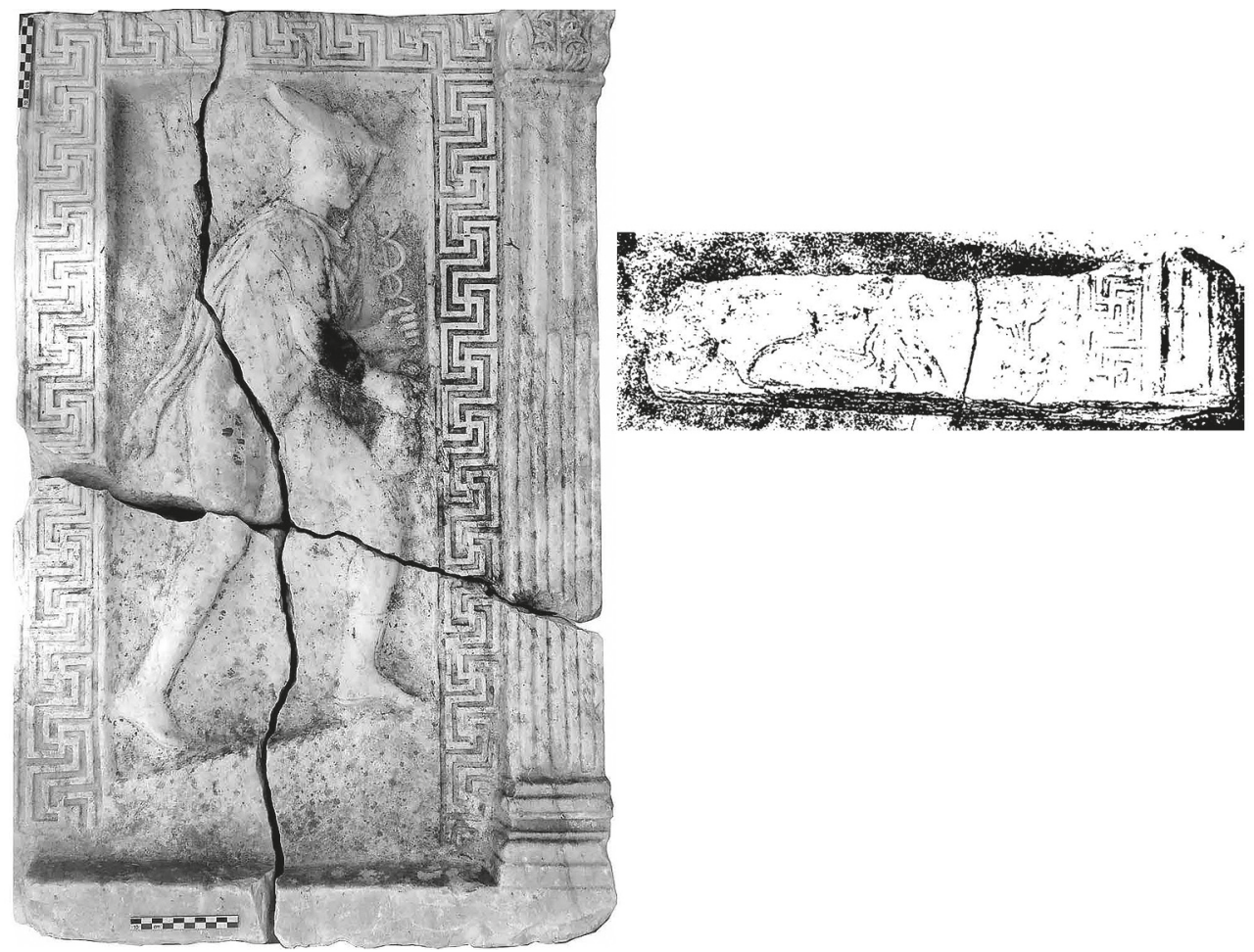

Fig. 10. Left: relief with Hermes at Corinth, Archaeological Museum. Right: fragment of relief, once at Klenia, now its whereabouts are not known. Courtesy of Dr. Eleni Korka

block has no other types of joints for the structural connection with the back wall, nor there are joints between them. At the back face of the block, an unfinished band indicates that the block probably belongs to a re-used quantity of marbles from a big scale marble monument.

The relief with its side blocks (still unknown), was probably attached to a preexisting wall, forming the positioning of portraits between pilasters as the representation proposes, up to a series of orthostates. The details of the elaboration of the relief, gives evidence about the technical failure of the material. At the lower left corner, there is a deeper carving because of this material failure. The meander band at this part becomes wider, as the technician followed an exact carved geometrical pattern. The incision of this pattern at the deeper lower left part of the relief is the reason of the distortion of the meander band. The material's initial failure can be seen also at the area of the face of Hermes.

In a post Byzantine church, a fragment of a similar relief has been documented, probably belonging to the same ensemble (Fig. 10).

As comparanda of this type of relief, the most exceptional example is the relief of Ara Pacis [2 and 13] in Rome. It has the same type of meander bands, the same deep carving at the inner surface of the block, in order to create a vivid almost three-dimensional relief, always between 

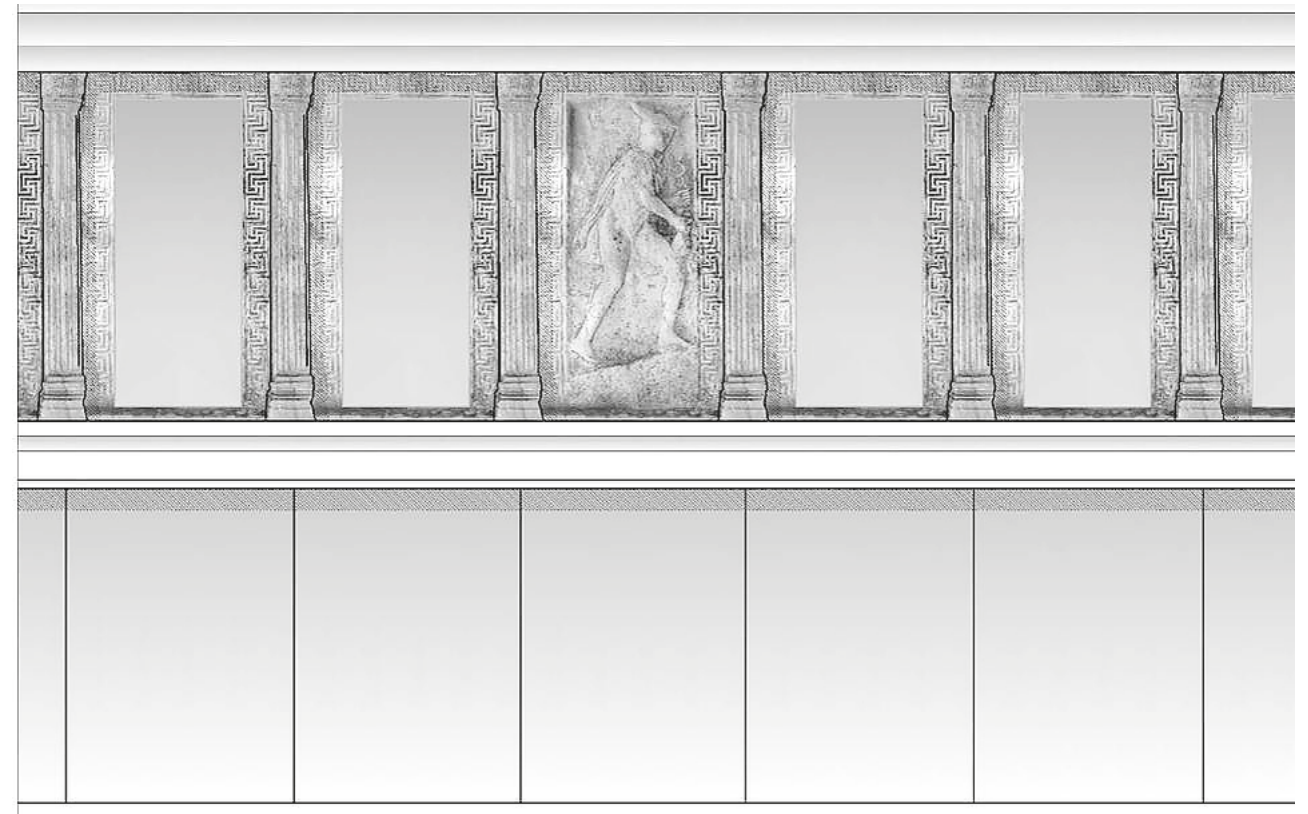

Fig. 11. Reconstruction drawing of ancient sekos, with Hermes' relief by Architect Dr. Michalis Lefantzis

decorated pilasters. Of course, the artistic and architectural product of Ara Pacis is beyond any comparison. There, even the orthostates are decorated.

The monument is one of the most important altars of the Roman period. The central civic monument was placed at the most crucial urban crossroad of the city of Rome [16].

The Hermes relief, most probably, belongs to a similar decorated precinct wall of an altar of smaller proportion at the central crossroad of the urban district of Tenea dated in the period of Augustus (Fig. 11).

The entire monument, from the dimensions of this single block, could be shaped not more than $5.00 \times 5.00 \mathrm{~m}$ with the height of $3.20 \mathrm{~m}$ maximum. Probably this significant civic monument could stand on a podium (Fig. 11).

Recently, near the excavation site, more than 25 scattered marble blocks have been identified pertinent to the same krepis found at the territory of ancient Tenea, and the hypothesis is that they form a small scale foundation of a precinct wall, most probably the same wall of the altar (Fig. 12 and 13). At the internal space of this perimeter wall, probably there was a small marble altar.

\section{The significant scattered architectural blocks and the discovery of a late Archaic Temple}

As this research continues during the last period of the excavation, some important architectural blocks have been found, including Ionic and Doric capitals and column drums from different buildings (Fig. 14). 


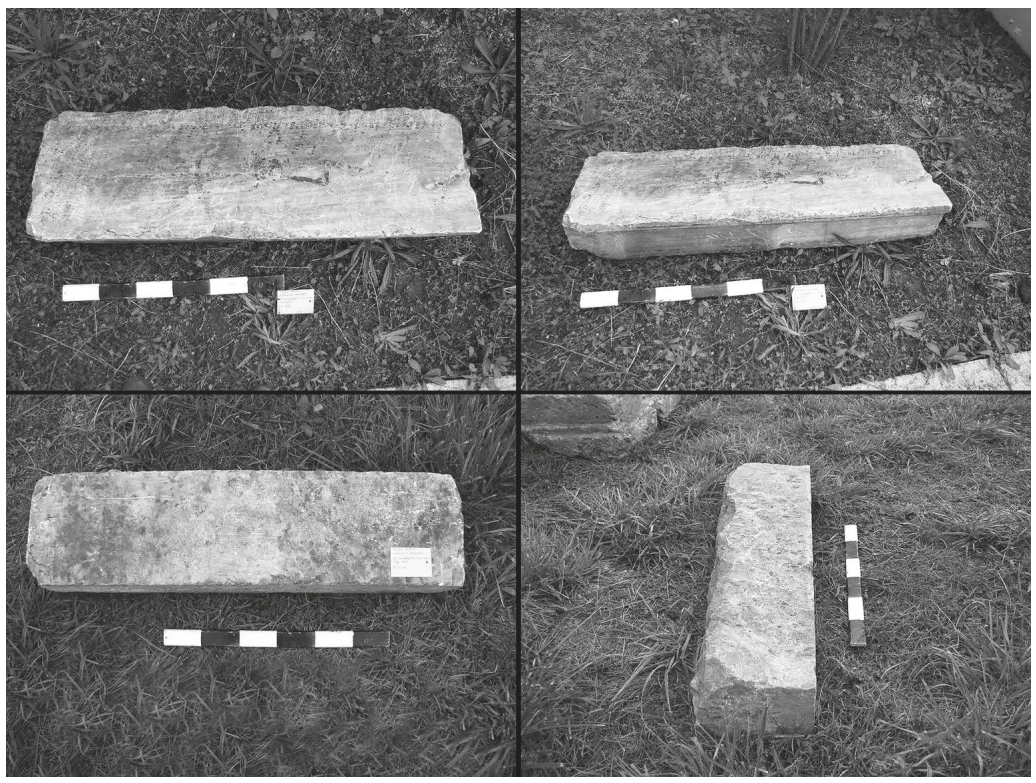

Fig. 12. Architectural elements from the excavation of Tenea, Chiliomodi, antiquities storeroom. Courtesy of Dr. Eleni Korka

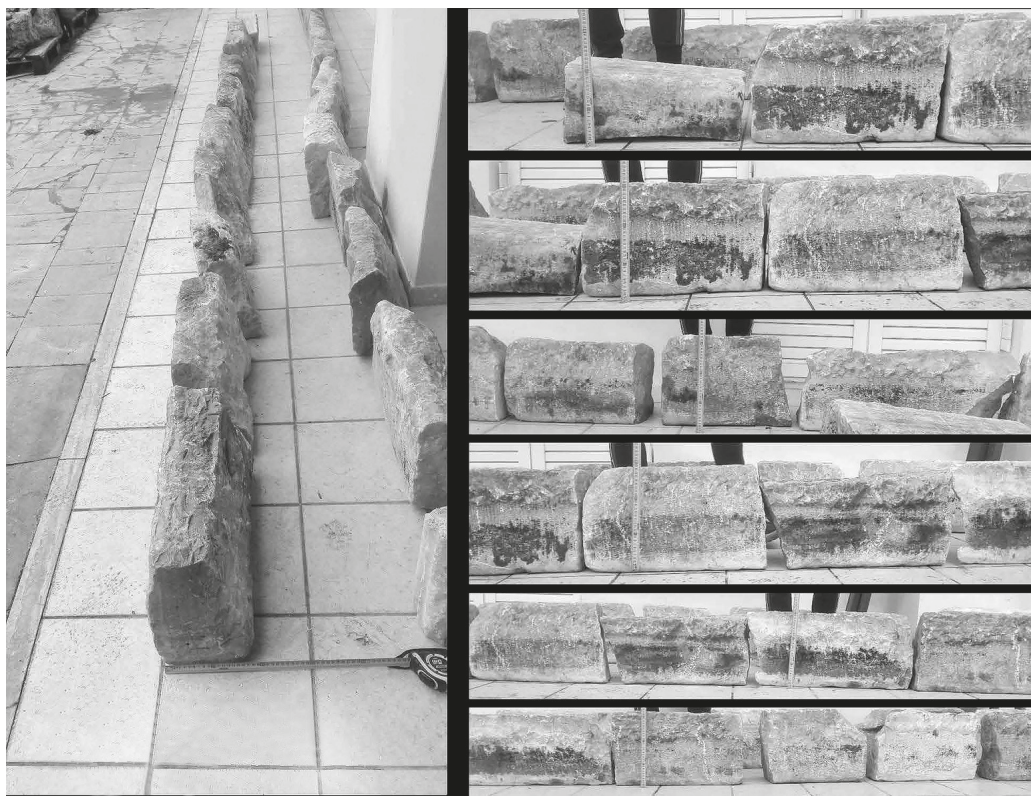

Fig. 13. Architectural elements from the excavation of Tenea, Chiliomodi, antiquities storeroom. Courtesy of Dr. Eleni Korka 


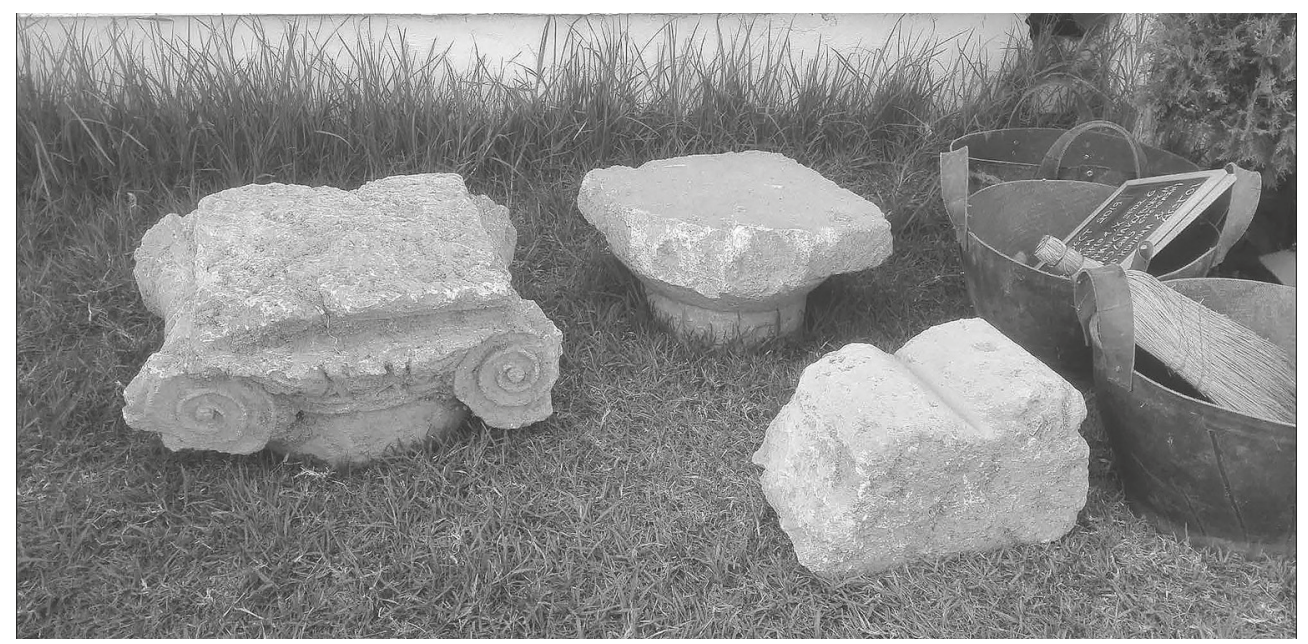

Fig. 14. Architectural elements from the excavation of Tenea, Chiliomodi, antiquities storeroom. Courtesy of Dr. Eleni Korka

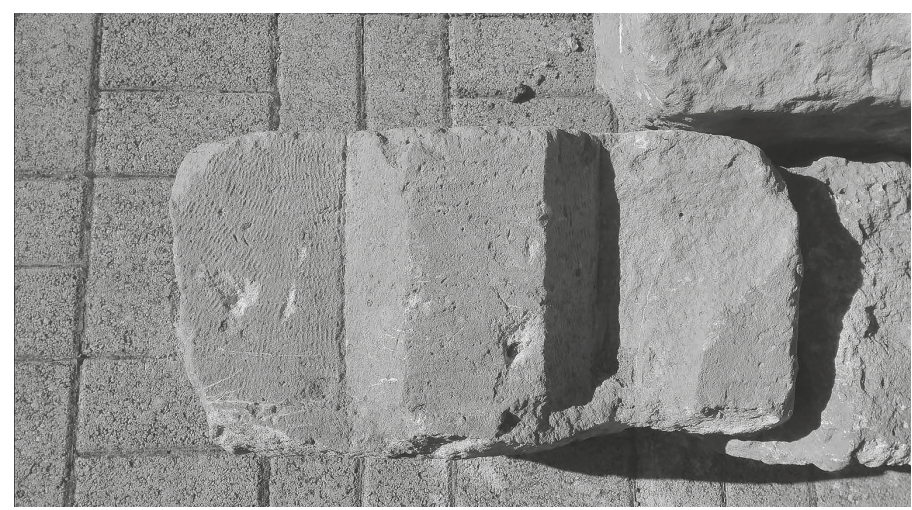

Fig. 15. Architectural elements from the excavation of Tenea, Chiliomodi, antiquities storeroom. Courtesy of Dr. Eleni Korka

Among these limestone blocks there were fragments of triglyphs (Fig. 15), fragments of a Doric architrave (Figs. 16 and 17) and column capital derived from the same building (Figs. 18 and 19).

Measuring the glyphs of the triglyph fragments, in which a part of the metopes is saved (Figs. 20 and 21), incorporated to the blocks, in relation with the taenia and the guttae of the epistyle, we found out that they belong to the same entablature of a middle scale Doric façade (Figs. 22-24).

The fragment of a Doric capital, without rings (Figs. 25) probably also belongs to this façade. The beginning of the flutes is elaborated with a tooth chisel and only a part of the echinus and the hypotrachelion were saved. 


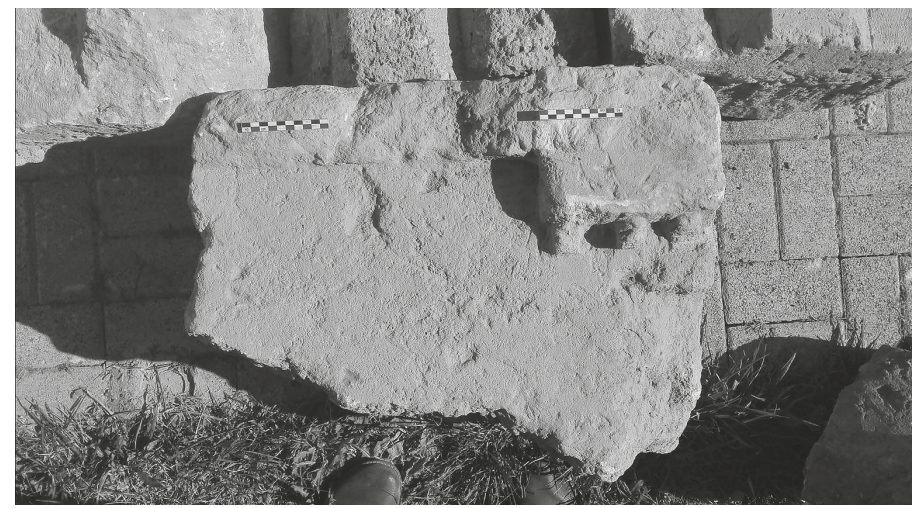

Fig. 16. Architectural elements from the excavation of Tenea, Chiliomodi, antiquities storeroom. Courtesy of Dr. Eleni Korka

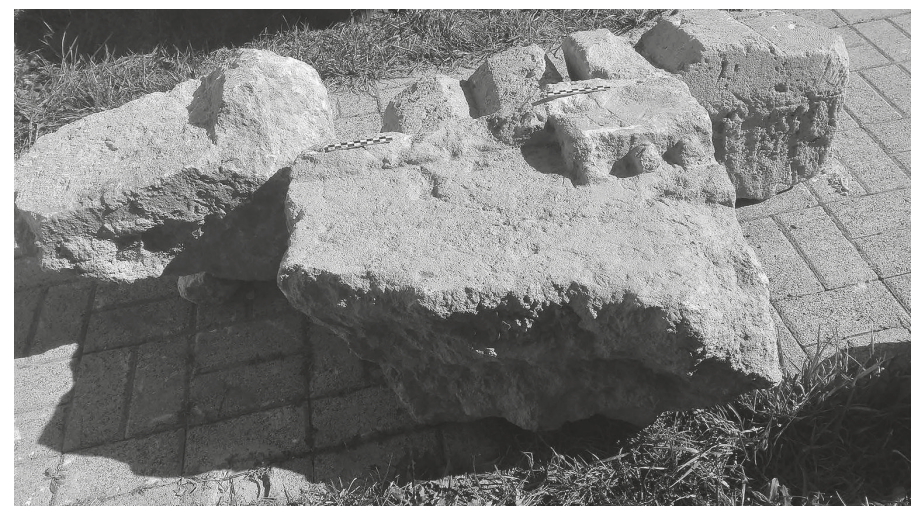

Fig. 17. Architectural elements from the excavation of Tenea, Chiliomodi, antiquities storeroom. Courtesy of Dr. Eleni Korka

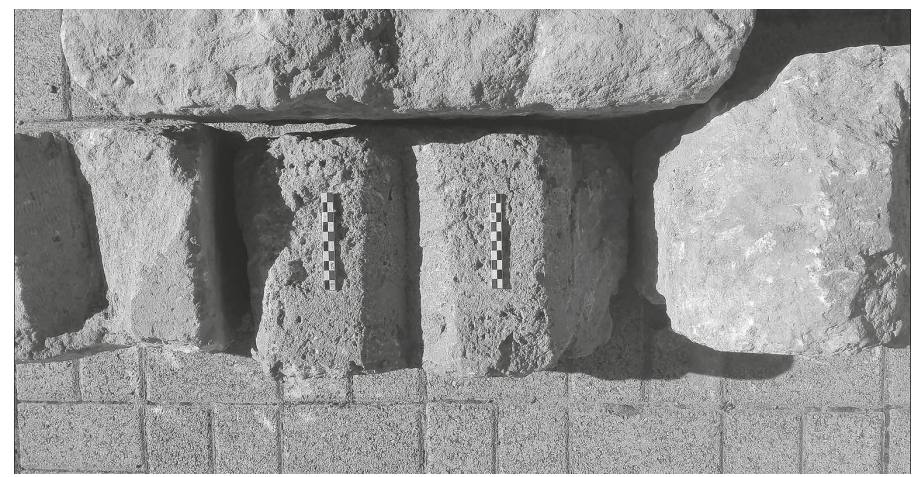

Fig. 18. Architectural elements from the excavation of Tenea, Chiliomodi, antiquities storeroom. Courtesy of Dr. Eleni Korka 


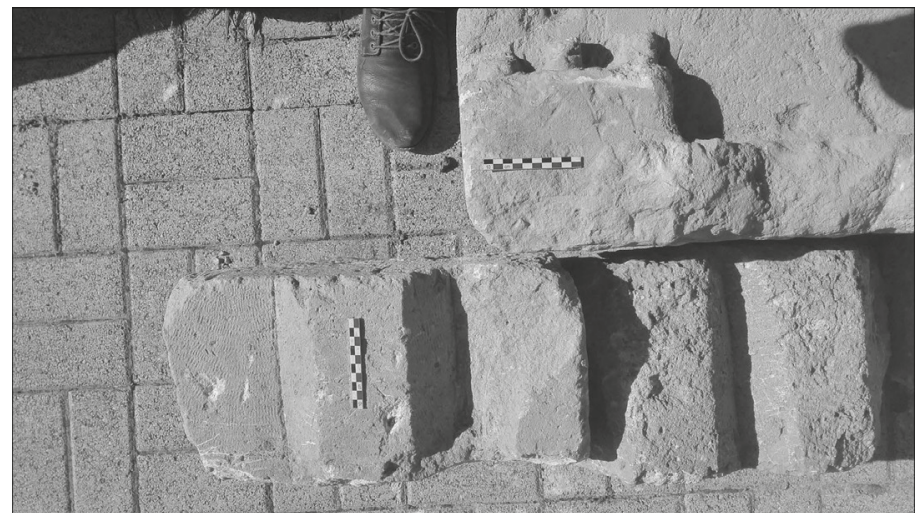

Fig. 19. Architectural elements from the excavation of Tenea, Chiliomodi, antiquities storeroom. Courtesy of Dr. Eleni Korka

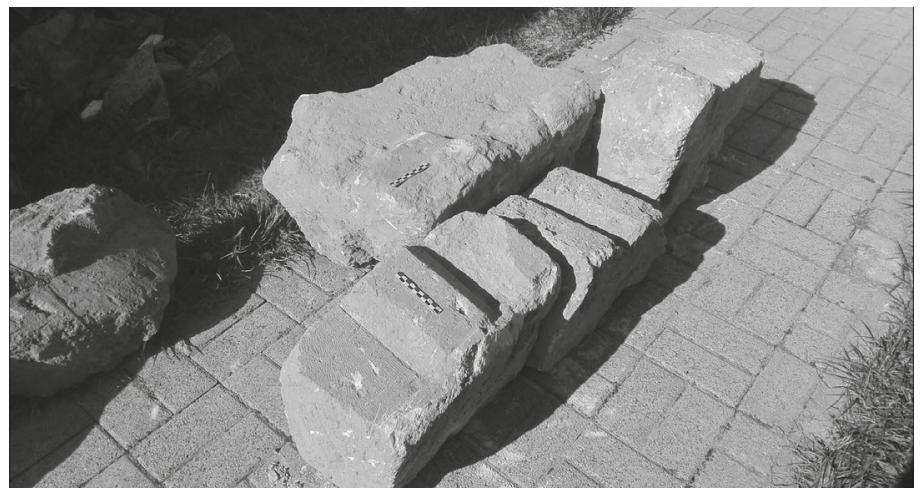

Fig. 20. Architectural elements from the excavation of Tenea, Chiliomodi, antiquities storeroom. Courtesy of Dr. Eleni Korka

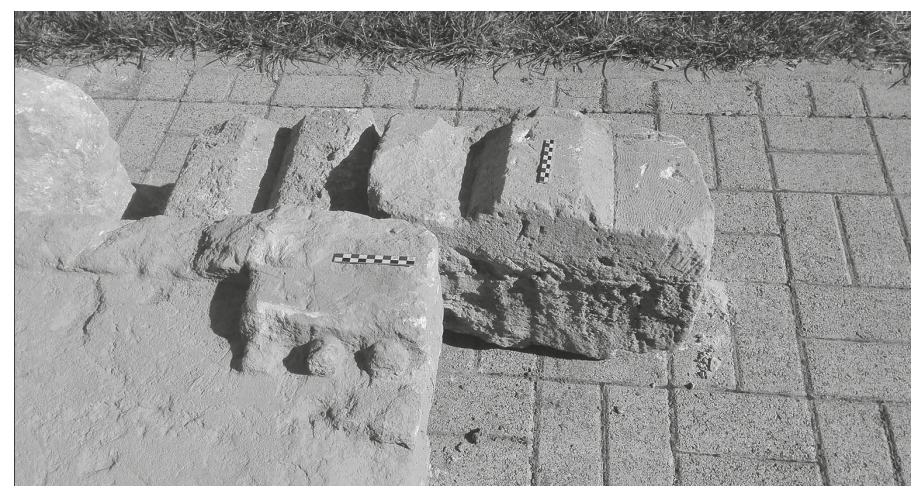

Fig. 21. Architectural elements from the excavation of Tenea, Chiliomodi, antiquities storeroom. Courtesy of Dr. Eleni Korka 


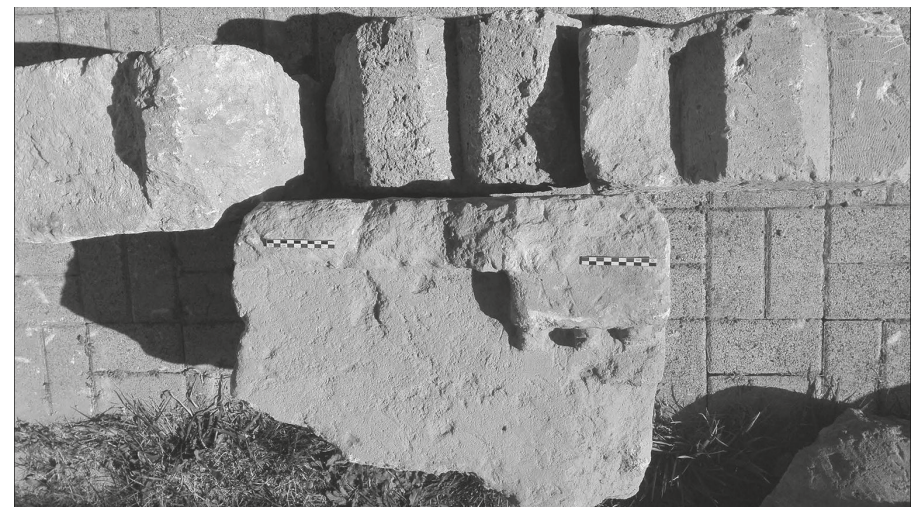

Fig. 22. Architectural elements from the excavation of Tenea, Chiliomodi, antiquities storeroom. Courtesy of Dr. Eleni Korka

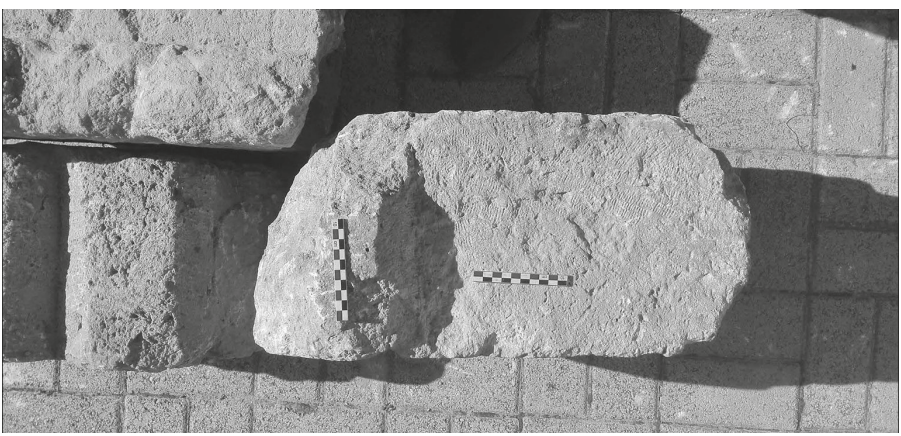

Fig. 23. Architectural elements from the excavation of Tenea, Chiliomodi, antiquities storeroom. Courtesy of Dr. Eleni Korka

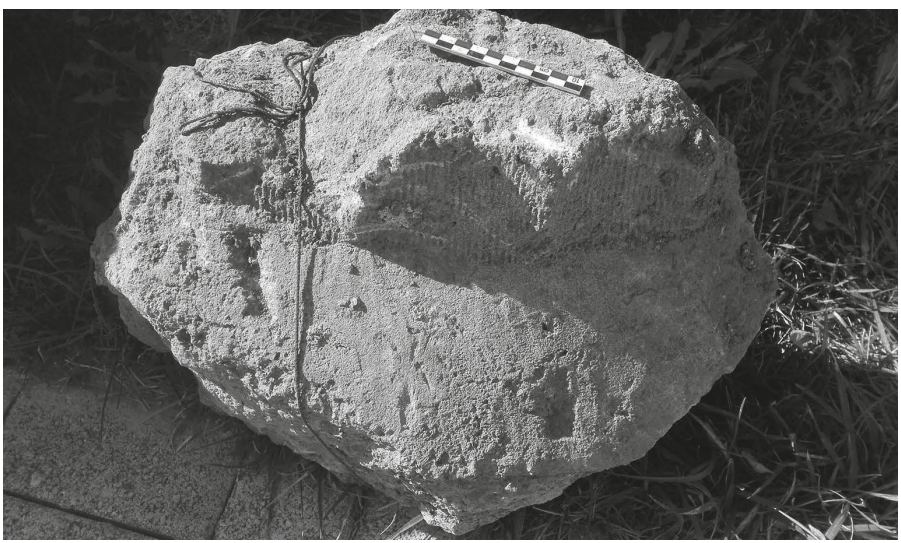

Fig. 24. Architectural elements from the excavation of Tenea, Chiliomodi, antiquities storeroom. Courtesy of Dr. Eleni Korka 


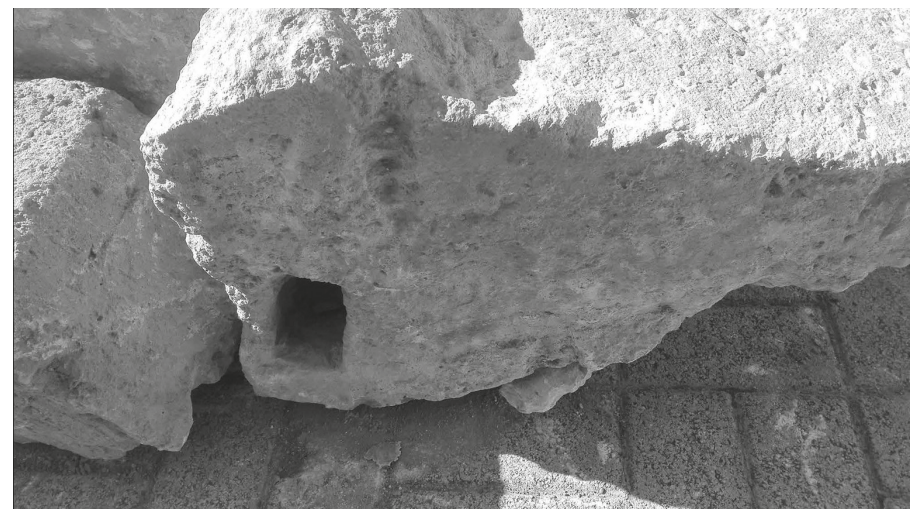

Fig. 25. Architectural elements from the excavation of Tenea, Chiliomodi, antiquities storeroom. Courtesy of Dr. Eleni Korka

The width of the triglyphs is measured to $56-57 \mathrm{~cm}$, identical is the dimension at the hypotrachelion of the capital at the level of the apophyge.

Also at these blocks, some lifting grooves have been found (named "lykos" in Greek), dated from the late Archaic period to the middle of Classical period (Figs. 26-29).

During the search for comparanda to these blocks, we initially thought that they could belong to a Doric propylon. After a preliminary analysis, we can say that they appear similar to those at the prostylon of the Thesaurus of Megara, at Delphi [8, 12 and 29]. The blocks of Tenea have the same dimensions and they form a similar building to this Thesaurus.

Based at the exact type of this monument, following the same dimensions and geometry for the formation of the front view, we tried to create an hypothetical representation of the blocks as part of the proposed entablature (Fig. 30) and finally present as a hypothesis the entire front view of the monument, which was probably an archaic naiskos (Fig. 31) situated very close to the present excavation site (Fig. 32).

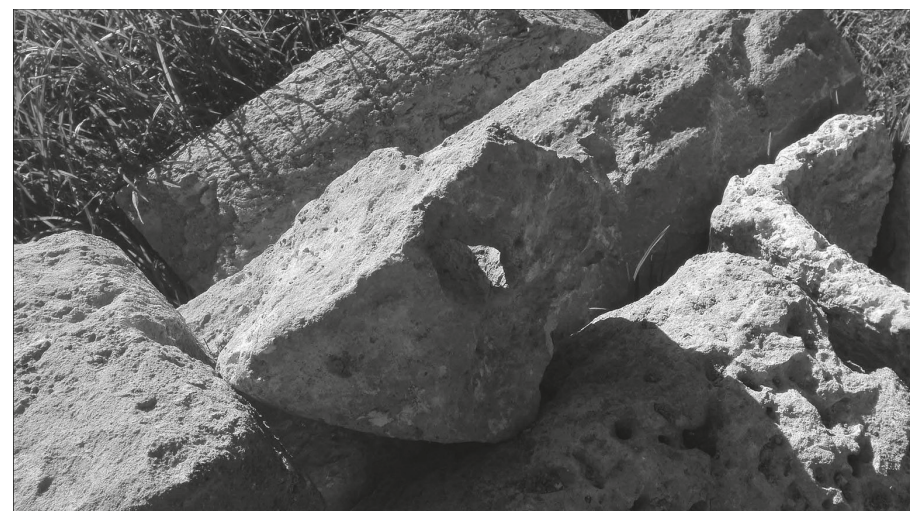

Fig. 26. Architectural elements from the excavation of Tenea, Chiliomodi, antiquities storeroom. Courtesy of Dr. Eleni Korka 


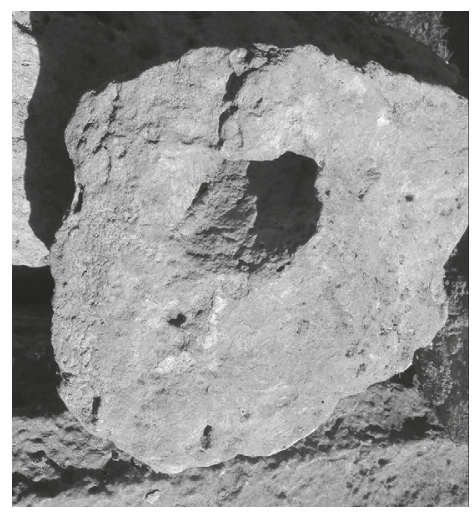

Fig. 27. Architectural elements from the excavation of Tenea, Chiliomodi, antiquities storeroom. Courtesy of Dr. Eleni Korka

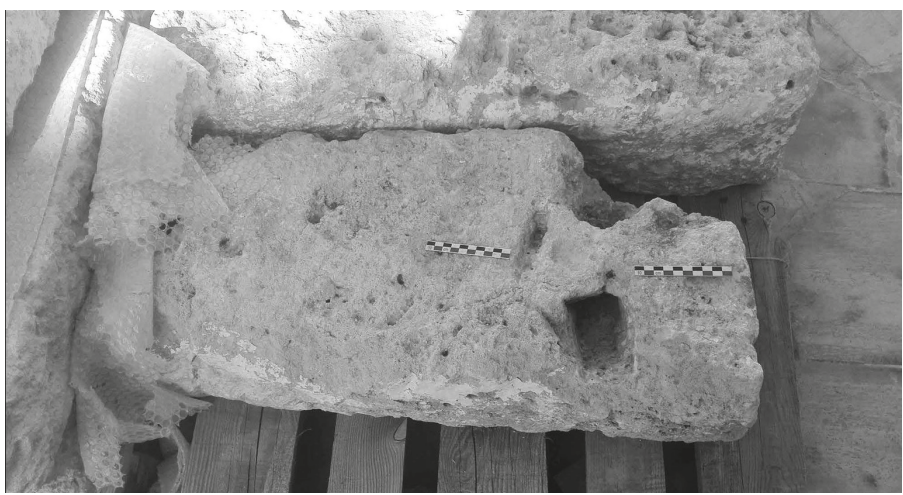

Fig. 28. Architectural elements from the excavation of Tenea, Chiliomodi, antiquities storeroom. Courtesy of Dr. Eleni Korka

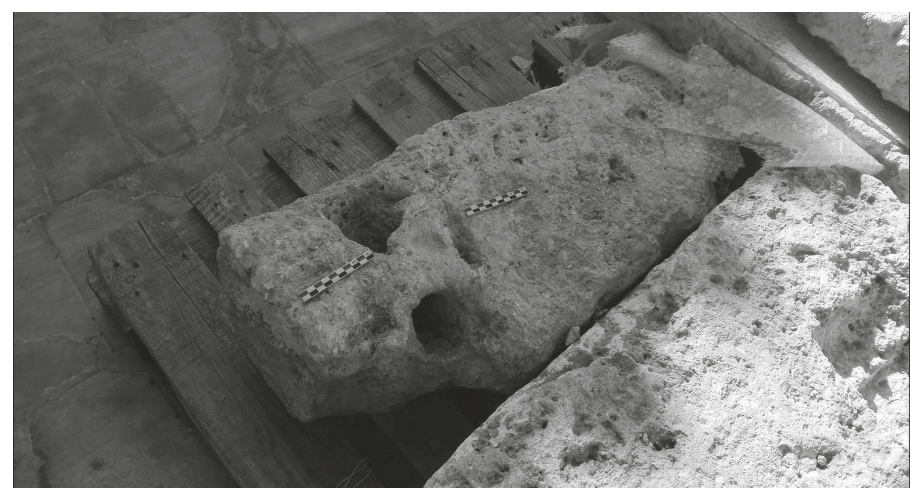

Fig. 29. Architectural elements from the excavation of Tenea, Chiliomodi, antiquities storeroom. Courtesy of Dr. Eleni Korka 


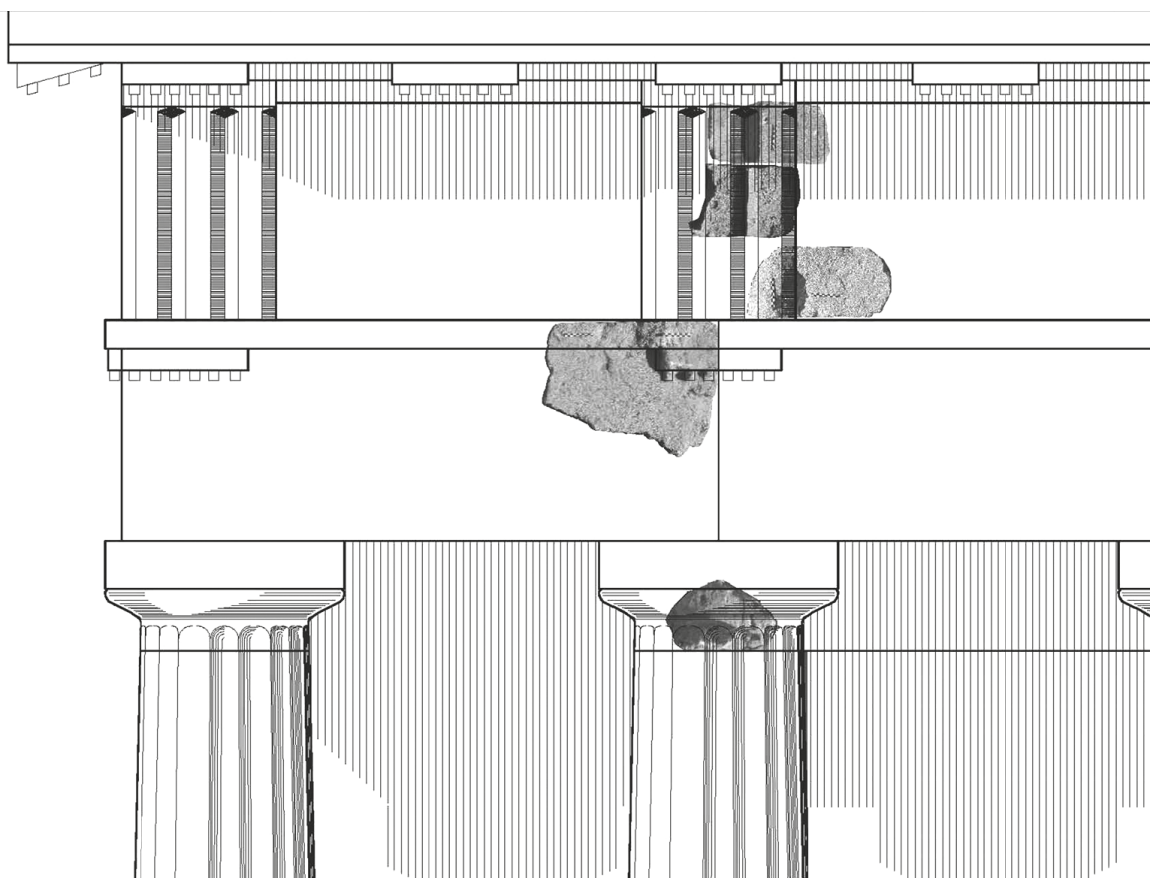

Fig. 30. Reconstruction drawing of the entablature of a naiskos or propylon at Tenea by Architect Dr. Michalis Lefantzis

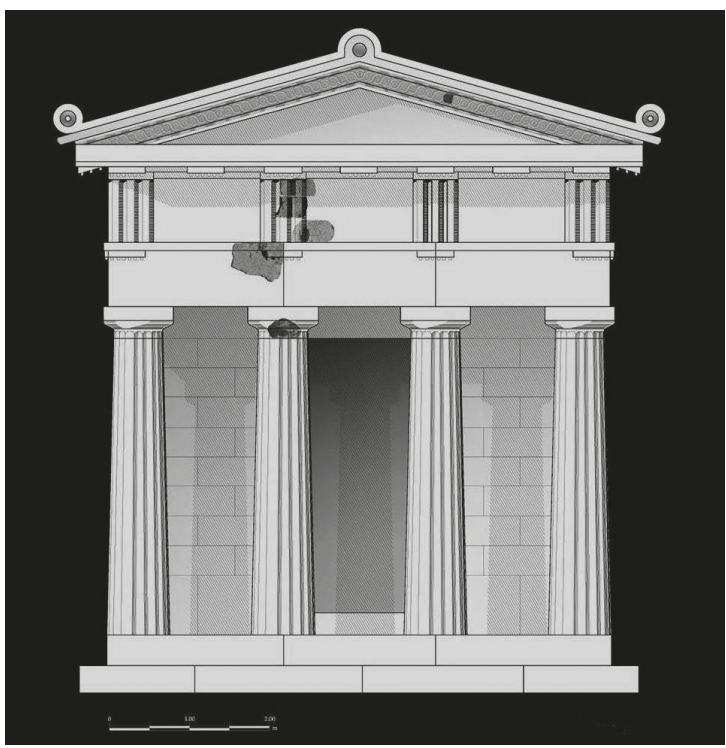

Fig. 31. Reconstruction drawing of late archaic naiskos at Tenea by Architect Dr. Michalis Lefantzis 

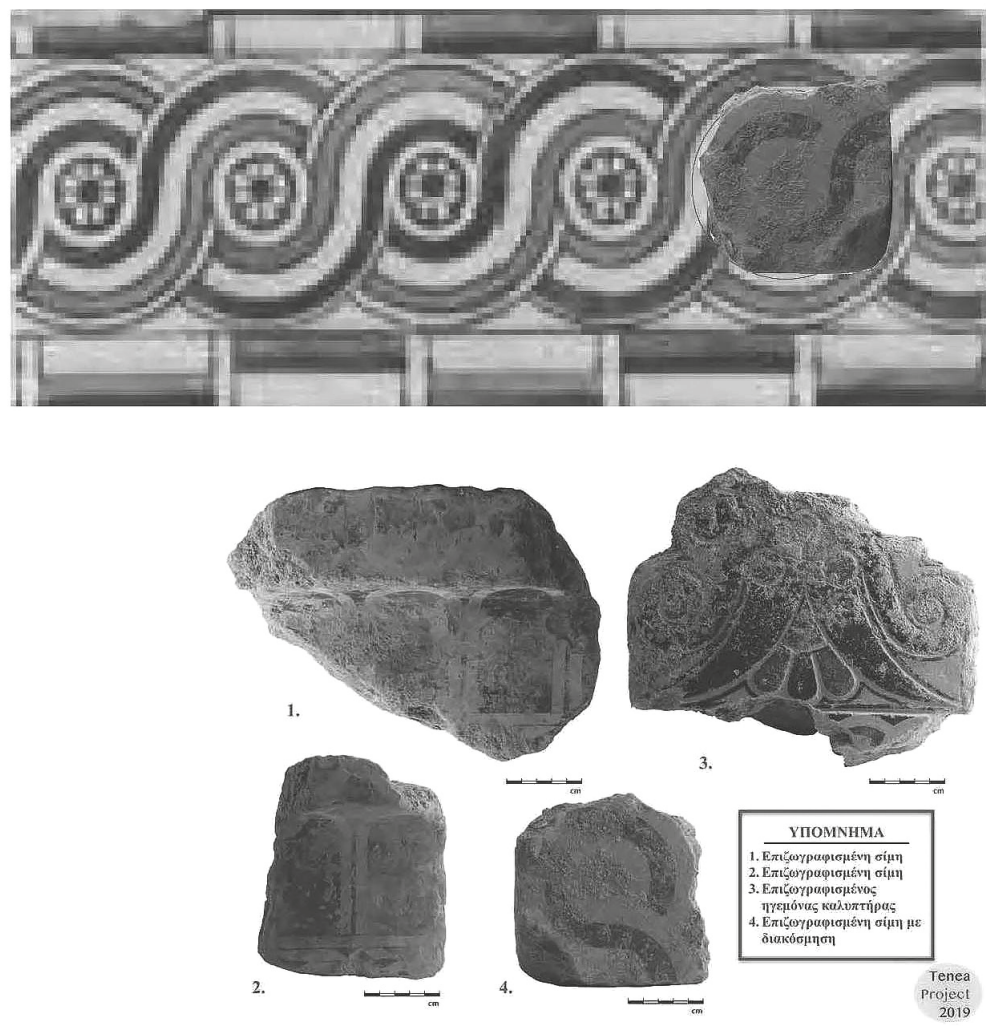

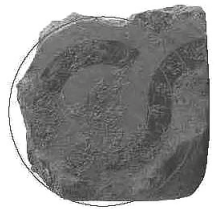

Reconstructioned detail of the archaic naiskos's ceramic pediment sima (Lefantzis 2019)

Fig. 32. Fragments of the sima of the late archaic naiskos at Tenea, Chiliomodi, antiquities storeroom. Courtesy of Dr. Eleni Korka

In the excavation of 2020, some new limestone fragmented parts of the same archaic prostylon have been found. Triglyphs, some architrave parts, column drums, and fragments of Doric capitals indicate the existence of the naiskos, leading to the conclusion that very close to the present point of the excavation it is possible to find the foundation of the archaic building.

\section{References}

1. Bol R. Amazones volneratae. Mainz, von Zabern Publ., 1998. 284 p. (in German).

2. Castriota D. The Ara Pacis Augustae and the Imagery of Abundance in Later Greek and Early Roman Imperial Art. Princeton, Princeton University Press Publ., 1995. 253 p.

3. Crow Ch. The Ara Pacis. History Today, no. 56, June 2006.

4. Corso A. Retrieving the Style of Cephisodotus the Younger. Arctos, iss. 48, 2014, pp. $109-136$.

5. Corso A. The Art of Praxiteles II. Rome, L'Erma di Bretschneider Publ., 2007. 303 p.

6. Corso A. Retrieving the Aphrodite of Hermogenes of Cythera. Hyperboreus, iss. 21-1, 2015, pp. 80-89.

7. Gregory T.E. The Roman Baths at Isthmia, Preliminary Report 1972-1992. Hesperia, iss. 64, 3, 1995, pp. 279-313. 
8. Hollinshead M. B. Adyton, Opisthodomos, and the Inner Room of the Greek Temple, Hesperia, iss. 68, 1999, pp. $189-218$.

9. Jockey P. Neither School nor Koine. Palagia O. (ed.). Regional Schools in Hellenistic Sculpture, Oxford, Oxbow Publ., 1998, pp. 177-184.

10. Johnson F. P. Sculpture, Corinth 9. 1. Harvard, Harvard University Press Publ., 1931. 158 p.

11. Karagiorga T.G. Der verkannte Protesilaos. Mitteilungen des Deutschen Archaeologischen Institut. Athenische Abteilung, iss. 110, 1995, pp. 207-233 (in German).

12. Klein N. L. Internationalism in Architecture: Olympia. Miles M.M. (ed.). A Companion to Greek Architecture. Chichester, Blackwell Publ., 2016, pp. 121-134.

13. Kleiner D. E. The Great Friezes of the Ara Pacis Augustae. Greek Sources Roman Derivatives and Augustan Social Policy. Melanges de l'école française de Rome, no. 90, 1978, pp.753-776.

14. Korka E.; Lagos C.; Syrrou M. An Early Byzantine Gold Hoard from Tenea, Corinthia. The Numismatic Society (forthcoming).

15. Koller M. Alte und neue Überlegungen zur Rekonstruktion der praxitelischen Kultbildbasis aus Mantineia. Hiller S. (ed.). Temenos. Vienna, 2002, pp. 83-89 (in German).

16. Lamp K. The Ara Pacis Augustae: Visual Rhetoric in Augustus' Principate, Rhetoric Society Quarterly, iss. 39, 2009, pp. 1-24.

17. Lattimore S. Meleager. Opuscula Romana, no. 9, 1973, pp. 157-166.

18. Lamprinoudakis B. K. Sanctuary of Apollo Maleatas of Epidauros. П.A.E. Proceedings of the Archaeological Society of Athens, vol. 147, 1992.

19. Nielsen I. Thermae et Balnea, vol.1, Text. Aarhus, Aarhus University Press Publ., 1990. 193 p.

20. Oulkeroglou A. The Bath Foundations in Macedonia during the Roman Imperial and Early Byzantine period, Doctoral Thesis. Thessaloniki, 2016 (in Greek).

21. Oulkeroglou A. The Baths Complex of the Central Road of Dion. Excavations 1977-2007, postdoctoral research. Thessaloniki, 2008.

22. Pafumi S. Una nuova replica da Siracusa dell'Apollo tipo Omphalos. Bollettino d'Arte, iss. 122, 2002, pp. 5584 (in Italian).

23. Pemberton E. Small and Miniature Vases at Ancient Corinth. Hesperia, iss. 89, 2, 2020, pp. 281-338.

24. Pochmarski E. Dionysische Gruppen. Vienna, Selbstverlag des Österreichischen Archäologischen Institutes Publ., 1990. 420 p. (in German).

25. Schroeder S. F. Roemische Bacchusbilder in der Tradition des Apollon Lykeios. Rome, Giorgio Bretschneider Publ., 1989. 216 p. (in German).

26. Scranton R.; Ramage E. S. Investigations at Kenchreai, 1963. Hesperia, iss. 33, 1964, pp. 134-145.

27. Stewart A. Hellenistic Freestanding Sculpture from the Athenian Agora, Part 1. Hesperia, no. 81-2, 2012, pp. 267-342.

28. Todisco L. Scultura greca del IV secolo. Milan, Longanesi Publ., 1993. 507 p. (in Italian).

29. Wescoat B. D. The Temple of Athena at Assos. Oxford, Oxford University Press Publ., 2012. 318 p.

30. Yegül F. Baths and Bathing in Classical Antiquity. New York, Architectural History Foundation Publ., 1992. $501 \mathrm{p}$.

Title. New Finds Regarding the Architecture and Sculptures of Ancient Tenea

Authors. Korka, Eleni - full doctor, director of the excavation at Tenea. Greek Ministry of Culture and Sports, Bouboulinas 20-22, GR10682, Athens, Greece. ekorka@otenet.gr ORCID: 0000-0001-5378-9090

Lefantzis, Michalis - full doctor. Greek Ministry of Culture and Sports, Bouboulinas 20-22, GR10682, Athens, Greece. lefantzismichaelis@gmail.com

Corso, Antonio - full doctor. Center of Messenian Archaeological Studies, Psaromilingou 33, GR10553, Athens, Greece. antoniocorso@hotmail.com ORCID:0000-0002-8090-4274

Abstract. Excavations in 2019 and 2020 in ancient Tenea revealed a main part of the city's central web with public buildings totaling approximately 1.100 square meters. In particular, part of a public bath complex of Roman times was excavated, as well as part of an area of the Archaic times of religious significance. Several fragmentary statues have been found in the excavation of ancient Tenea and illustrate the visual culture of this centre from the severe style period to the late Hellenistic times. Moreover a relief of Dionysus held by a Satyr is walled in the main Church of Chiliomodi and should be dated in the Antonine times. During the recent period of the Tenea excavation, some important architectural blocks have been found, including Ionic and Doric capitals and column drums from different buildings. Among these limestone blocks there were fragments of triglyphs, a part 
of a Doric epistyle and part of a Doric column capital derived probably from the same building. Measuring the glyphs of the triglyph fragments in which a part of the metopes is saved, incorporated to the blocks, in relation with the taenia and the guttae of the epistyle, we found out that they belong to the same entablature of a middle scale Doric façade. To this façade probably belongs also the fragment of a Doric capital, without column's rings. The beginning of the flutes is elaborated with a tooth chisel and only a part of the echinus and the hypotrachelion is saved. The width of the triglyphs is measured to $56-57 \mathrm{~cm}$, identical dimension to the hypotrachelion of the capital at the level of the apophyge. Also at these blocks some lifting grooves have been found (named "lykos" in Greek), dated from the late archaic period until the middle of classic. During the research for comparanda to these blocks we initially thought that they could belong to a Doric propylon. After a preliminary analysis we can say that they look similar to those at the prostylon of the Thesaurus of Megara, at Delphi. The blocks of Tenea have the same dimensions and they form a similar building to this Thesaurus. Based on the exact type of this monument, following the same dimensions and geometry for the formation of the front view we tried to create an hypothetical representation of the blocks as part of the proposed entablature and finally, present as an hypothesis the entire front view of the monument, which was probably an archaic naiskos, situated very near to the present excavation site.

Keywords: Tenea, baths, temple of Apollo, Artemis, Aphrodite, Dionysus, Satyr

Название статьи. Новые находки, касающиеся архитектуры и скульптур Древней Тенеи

Сведения об авторах. Корка Элени - доктор, директор раскопок в Тенее. Министерство культуры и спорта Греции, Бубулинас 20-22, GR10682, Афины, Греция. ekorka@otenet.gr ORCID: 0000-0001-53789090

Лефанцис Михалис - доктор. Министерство культуры и спорта Греции, Бубулинас 20-22, GR10682, Афины, Греция. lefantzismichaelis@gmail.com

Корсо Антонио - доктор. Центр Мессенских археологических исследований, Псаромилингу 33, GR 10553, Афины, Греция. antoniocorso@hotmail.com ORCID:0000-0002-8090-4274

Аннотация. Недавними раскопками (под рук. д-ра Елены Корка) в Тенее, находившейся в античное время несколько южнее Коринфа, обнаружена значительная часть территории центра города и римские городские бани. За последние годы здесь были обнаружены значимые детали разных архитектурных сооружений - ионические и дорические капители и барабаны колонн. В числе известняковых фрагментов - обломки триглифов, часть дорического эпистиля и колонны, вероятно, относящиеся к одному зданию. Были сделаны замеры глифов на тех триглифах, вместе с которыми единым блоком сохранились остатки метоп. При их сопоставлении с тениями и гуттами эпистиля оказалось, что они принадлежат антаблементу одного фасада дорической постройки средних размеров. К этому же фасаду, по всей видимости, относится и фрагмент дорической капители без валиков. Окончания каннелюр проработаны зубилом, эхин и гипотрахелион сохранились лишь частично. Предварительный анализ, как нам представляется, указывает на близость постройки известному простилю - сокровищнице мегарцев в Дельфах. Сохранившиеся тенейские фрагменты имеют те же размеры и образуют постройку того же облика, что и упомянутая выше сокровищница. Исходя из того, что памятник относится к конкретному типу построек, следуя размерам и общей геометрии, образующей внешний вид фасада, считаем возможным предложить гипотетическую реконструкцию расположения блоков на антаблементе и воссоздать полный облик фасада здания - вероятно, архаического наиска, находившегося в непосредственной близости от участка, где сегодня ведутся раскопки. Находки скульптурных фрагментов позволяют пролить свет на историю художественной культуры этого античного центра. Среди находок: а. фрагмент, возможно, культовой статуи Аполлона Тенейского (Strabo 8. 380), относящейся к типу Аполлона Омфала; b. другой фрагмент, похоже, принадлежал статуе, относящейся к типу, известному как «тип Протесилая»; с. левый угол фронтона; d. фрагмент, видимо, принадлежавший статуе Артемиды одного из известных типов - Дрезденской, Версальской или Мальтийской; е. фрагмент скульптуры типа Мелеагра работы мастера скопасовского круга; f. Статуэтка Афродиты Книдской; g. Статуэтка Афродиты Стефанусы (Plin. 34, XIX, 69); и, наконец, h. Находящийся в стадии изучения рельеф с изображением Диониса, которого поддерживает Сатир - рельеф был вмонтирован в стену церкви в современной деревне Хилиомоди, находящейся выше места расположения Тенеи, и, как считается, происходит из [здания] театра. Описанные находки позволяют строить предположения относительно городского пантеона и судить об особенностях изобразительной культуры города от эпохи строго стиля до периода владычества Римской империи.

Ключевые слова: Тенея, бани (термы), храм Аполлона, Артемида, Афродита, Дионис, Сатир 